\title{
LEGAL PROTECTION TO WOMEN AND CHILDREN AS HUMAN TRAFFICKING VICTIMS IN VICTIMOLOGY PERSPECTIVE (Study in Banyumas Region) $^{\Omega}$
}

\author{
${ }^{1}$ Rani Hendriana, ${ }^{2}$ Rindha Widyaningsih, ${ }^{1}$ Dessi Perdani Yuris Puspita Sari \\ ${ }^{1}$ Faculty of Law Universitas Jenderal Soedirman Purwokerto, Indonesia \\ 2 Faculty of Humanities Universitas Jenderal Soedirman Purwokerto, Indonesia \\ E-mail: rani_capu@yahoo.com
}

\begin{abstract}
Legal protection to women and children as human trafficking victims in Banyumas, to date has not been viewed in victimology perspective. Intriguing issues has been analyzed regarding legal protecttion and factors that tend to inhibit its implementation in victimology perspective. This study used a qualitative research method and sociological juridical approach. The results showed that the third goal of victimology has not been reached, in which the legal protection is not yet fully leads to the needs of victims. The main factor that tends to influence is the correlation between the victim's fault in the occurrence of human trafficking and the victim's response to legal protection, while other inhibiting factors are the legal structure, legal substance, and society legal culture.
\end{abstract}

Keywords: legal protection, women, children, human trafficking, victimology

\begin{abstract}
Abstrak
Perlindungan hukum terhadap perempuan dan anak korban human trafficking di Kabupaten Banyumas, selama ini belum berpijak pada perspektif Viktimologi. Permasalahan menarik dikaji mengenai perlin-dungan hukum dan faktor yang cenderung menghambat pelaksanaannya dalam perspektif Viktimologi. Penelitian ini menggunakan metode penelitian kualitatif, dengan pendekatan yuridis sosiologis. Hasil penelitian menunjukkan bahwa tujuan Viktimologi ketiga belum tercapai, di mana perlindungan hu-kum belum sepenuhnya mengarah pada kebutuhan korban. Faktor utama yang cenderung menghambat yakni adanya korelasi antara kesalahan korban dalam terjadinya human trafficking dengan respon kor-ban terhadap perlindungan hukumnya, sedangkan faktor lain yang turut menghambat adalah faktor struktur hukum, substansi hukum, dan budaya hukum masyarakat.
\end{abstract}

Kata kunci: perlindungan hukum, perempuan, anak, human trafficking, viktimologi

\section{Introduction}

The International Organization for Migration (IOM) states that since 2005 it has identified and assisted trafficking victims in Indonesia around 3,339 people, in which nearly $90 \%$ of the victims are women, and more than $25 \%$ are children. ${ }^{1}$ Furthermore, one of the victims' home areas in Indonesia is Banyumas Regency.

$\Omega \quad$ This article is the summary of the research result, funded by DIPA Universitas Jenderal Soedirman with contract Number 2378/UN.23.14/PN/2017, 1 March 2017.

1 Maslihati Nur Hidayat, "Upaya Pemberantasan dan Pencegahan Perdagangan Orang Melalui Hukum Internasional dan Hukum Positif Indonesia", Jurnal Al-Azhar Indonesia Seri Pranata Sosial, Vol. 1 No. 3, March 2013, p. 163.
The data of human trafficking case in Banyumas Regency is shown in the following table.

Table 1. Report of Banyumas Trafficking Case Handling Data in 2015 to 2016

\begin{tabular}{l|l|l|l}
\hline Year & $\begin{array}{l}|c| \\
\text { Victim } \\
\text { Identification }\end{array}$ & Process & Verdict \\
\hline $\begin{array}{l}\text { (3 cases) } \\
\text { 1 victim } \\
\text { (woman-16 } \\
\text { years old) }\end{array}$ & $\begin{array}{l}\text { Legal } \\
\text { Process }\end{array}$ & $\begin{array}{l}\text { Demands } \\
6 \text { years, 4 } \\
\text { years } \\
\text { verdict }\end{array}$ \\
\cline { 2 - 4 } & $\begin{array}{l}\text { 1 victim } \\
\text { (woman-17 } \\
\text { years old) }\end{array}$ & $\begin{array}{l}\text { In Legal } \\
\text { Process }\end{array}$ & - \\
\cline { 2 - 4 } & $\begin{array}{l}\text { 2 victims } \\
\text { (women-15 } \\
\text { and 19 years } \\
\text { old) }\end{array}$ & $\begin{array}{l}\text { Counseli } \\
\text { ng-Inte- } \\
\text { gration }\end{array}$ & $\begin{array}{l}\text { Repatria- } \\
\text { tion from } \\
\text { Central } \\
\text { Java Pro- } \\
\text { vince }\end{array}$ \\
\hline
\end{tabular}




\begin{tabular}{l|l|l|l}
\hline $\begin{array}{l}2016 \\
\text { (1 case) }\end{array}$ & $\begin{array}{l}\text { 2 victims } \\
\text { (women-16 } \\
\text { and 15 years } \\
\text { old) }\end{array}$ & $\begin{array}{l}\text { Legal } \\
\text { Process }\end{array}$ & $\begin{array}{l}\text { Demands } \\
5 \text { years, 6 } \\
\text { years } \\
\text { verdict }\end{array}$ \\
\hline
\end{tabular}

Source : Integrated Service Center for the Handling and Protection of Gender and Child Abuse Victims in Banyumas Regency

Based on the above data, it can be described that the human trafficking victims revealed in Banyumas are women and only one victim is classified as an adult. This indicates that women and children are riskier becoming victims than men and adults. Most victims experienced sexual exploitation. Indeed, the data above are only some of the cases revealed there are still many cases of human trafficking in Banyumas which have not been revealed. Therefore, it is not surprising to be "iceberg phenomenon". Victims and witnesses Reports are the determinant of starting point to disclose a case; because of the characteristics of human trafficking is organized.

The lack of legal protection based on victimology perspective is the main problem. Victimology is a science of victims which does not only aim to create policies to reduce victims' suffering, but also it analyzes various losses of victims and looks for the causes of victimization. ${ }^{2}$ Through this point of view, the study does not only find a form of legal protection in accordance with victims' needs, but also it discovers factors which tend to affect the implementation of victims legal protection.

Based on the above explanation, there are two problems discussed in this article. first, how is the legal protection to women and childrenas human trafficking victims in Banyumas Regency through victimology perspective? Second, what factors which tend to hamper the implementation of legal protection to women and childrenas human trafficking victims in Banyumas Regency through victimology perspective are.

\section{Research Method}

Iswanto and Angkasa, 2011, Viktimologi, Purwokerto: Faculty of Law Universitas Jenderal Soedirman, p.15.
This research uses qualitative research method, with sociological juridical approach. This approach emphasizes the disclosure of empirical phenomenon, for constructing law as a reflection of society life. ${ }^{3}$ Law is assumed to be something that is not autonomous so that its validity is determined by non-juridical factors. ${ }^{4}$ The informant as the research sample is officers of Banyumas Police Resort and Integrated Service Center for Handling of Gender and Child Abuse Victims Protection of Banyumas Regency (PPT-PKBGA), because it is seen as related institutions which have capacity in legal protection of human trafficking victims. Purposive Sampling is done to get representative sample.

\section{Discussion}

Legal protection to women and childrenas Human Trafficking Victim in Banyumas Regency According to Victimology Perspective

Victim protection in positive law is an abstract or indirect protection. As a result, victim protection is not direct and in concreto. ${ }^{5}$ Based on that matter, the existence of Law Number 21 Year 27 on Eliminating Criminal Act of Human Trafficking, Law Number 43 Year 2014 on Changes of Law Number 23 Year 2002 on Children's Protection and Law Number 31 Year 2014 on Changes of Law Number 13 Year 2006 on Witness and Victim Protection; those regulations basically are legal protection in abstracto as well as aim to realize the third goal of victimlogy which is "to develop a system of measure for reducing human suffering."

The concept of protection for criminal victim according to Barda Nawawi Arief can be seen from two meanings, which have two characteristics of protection that can be given directly through law. First, preventive, in legal protection, aims to protect the people in order

3 Rahadi Wasi Bintoro, "Implementasi Mediasi Litigasi Di Lingkungan Yurisdiksi Pengadilan Negeri Purwokerto", Jurnal Dinamika Hukum, Vol. 14 No. 1, January 2014, p. 16.

4 Zulfadli Barus, “Analisis Filosofis Tentang Peta Konseptual Penelitian Hukum Normatif dan Penelitian Hukum Sosiologis", Jurnal Dinamika Hukum, Vol. 13 No. 2, May 2013, p. 312.

5 J. Hattu, "Perlindungan Hukum Terhadap Korban Kejahatan Ekonomi Di Bidang Perbankan”, Jurnal Sasi, Vol. 16 No. 4, October- December 2010, p. 39. 
to avoid becoming a victim. Second, repressive is a protection to earn assurance or/legal compensation above one's suffering or/loss after becoming a criminal victim. ${ }^{6}$

Based on the result of interview with research informants from Banyumas Police Officials, we can understand that in this issue, $\mathrm{Ba}$ nyumas Police provide legal protection which is preventive in form of socialization as a way to avoid any creation of criminals and victims. Moreover, legal protection given by PPT-PKBGA is more repressive because according to research informants from PPT PKBGA officials that they prefer to handle the victim from reporting until to summoning to court. This could be criticized because legal protection does not provide the peoples need in order to prevent any potential doer or victim.

Looking from Victimology perspective, the matter above basically associated with the first purpose of victimology; namely, "to analyze the manifold aspect of the victim's problem" and the second purpose which is "to explain the causes for victimization". ${ }^{7}$ Discussing about victims suffering or lost, according to informants from Banyumas Police Officials, there are two types of victims of human trafficking. The first is the real victim of human trafficking (feeling like a victim), therefore the lost experienced by them are physic, physical, sexual and economy suffering. Second, voluntarily human trafficking victim (does not feel like a victim), where victims agree to be the object of human trafficking; therefore, the victims do not feel any suffering.

Based on these types of victim, it shows that human trafficking is very dangerous because there is voluntarily victim with various motivations behind them. With this matter, legal protection is a preventive protection which is essential for the people for "early detection and early warning".

The form of legal protection which is repressive has been applied by PPT-PKBGA and
Banyumas Police to victims of human trafficking where those preventions aim to fulfill the rights of human trafficking victim as regulated in Law Number 21 Year 2017. The law stated about the confidentiality of victims and families identity (Article 44-46), rights to receive protection from threats which may endanger themselves, their soul and/or properties (Article 47), and right to receive physical rehabilitation, social rehabilitation, repatriating and social reintegration from government (Article 51-53). The rights of victims also regulated in Law Number 31 year 2014. Even though this is the responsibility of LPSK, Banyumas Police and PPT-PKBGA also need to fulfill the rights of victims as mentioned in Article 5 Paragraph (1) and Article 6.

Related to restitution as regulated in Article 48 Law Number 21 Year 2007, based on research informants' information from Banyumas Resort Police, states that Resort Police only gave unwritten recommendation to public prosecutor (JPU), and it has never been practiced yet. Based on the interview result with the research informant from PPT-PKBGA, it is obtained information that restitution also has not been done by PPT-PKBGA, which the compensation from the perpetrator to victim is more likely non-litigation handling. In provision of social habitation is not in the step of giving skill or economic needs yet, therefore PPT-PKBGA tries to cooperate with social services so the victim can get help in form of working's equipment capital.

This thing should be criticized as the provision is material in form of restitution, ${ }^{8}$ initiative and submission of restitution by the victim are really need, however the victim of human trafficking needs to get information and guidance in submitting restitution. Moreover, psycho-social rehabilitation is still not optimal, whether it is a formal education or informal (job skills), it will dissociate children to grow and develop properly. Along with the existence of human trafficking victim that is pregnant and

\footnotetext{
Sudaryono, “Kekerasan Pada Anak: Bentuk, Penanggulangan, dan Perlindungan Pada Anak Korban Kekerasan”, Jurnal Ilmu Hukum, Vol. 10 No. 1, March 2007, p. 95.
} 
giving birth, it is certainly needed woman's independency in financial.

Repressive law protection, in this case talks about implementation from the third aim of Victimology that is "to develop a system of measure for reducing human suffering", it can be achieved optimally if it is referring to the first aim of Victimology. It can be interpreted that implementation of legal policy for human trafficking victim should be based on analysis of the victim's needs according to the problem and the loss. Refer to that case, so that the third aim of Victimology is not optimally achieved yet.

Factors in Victimology Perspective that Tend to Inhibit the Implementation of Legal Protection to Women and Children as Human Trafficking Victim in Banyumas

It is a logic matter of women and children's biological weaknesses (physically and psychologically) and women's level as 'subordinate' in patriarchy system that make them having more risk as human trafficking victim than man and adult. The existence of civilization and development do not change those weaknesses significantly. Yet the desire of economic improvement, the social status achievement and lifestyle can trigger woman and children as human trafficking victim.

Behaviour and perspective of victim in handling human trafficking are the main factors that tend to influence the success implementation of law protection for human trafficking victim. The result of the research shows that, there is a correlation between implementation of it and the role or mistakes of the victim in human trafficking. This thing indicates the analysis of victim's mistakes in the occurrence of crime, which based on second aim of Victimology "to explain the causes for victimization", cannot be avoided.

Some of the research informants tend to give answers that there are types of woman and children that cause the human trafficking. Firstly, "the innocent one", in this case the victim has no role in human trafficking. Based on an interview with the informant from Resort
Police Banyumas, this type of victim is usually children that they are so innocent so it makes them easy to be deceived, trapped or forced. Refer to typology of victim from Mendelsohn. This is the first type which called as "The completely innocent victim". According to Mendelsohn, ${ }^{9}$ that the first type "the completely innocent victim", these individuals are in no way responsible for their own victimization. Instead, these individuals are victimized simply because of the nature of who they are (i.e., a child). This victim is considered as ideal victim, it tends to happen to children and they are also not aware that they are the victims. ${ }^{10}$

Secondly, it is "victim because of their ignorance or victim with minor guilt". Based on the interview with research informant from Police Resort of Banyumas, this victim is little bit same with victim's type above. Yet, there are fault from the victim, they are easily trust people, ignorance, and a behavior that indicated openness. Even it's possible that the victim willing to use fake document to searching for a job but they did not know being a target of human trafficking. ${ }^{11}$ According to victim typology from Mendelsohn, the second type called as "the victim with minor guilt and the victim due to his ignorance". ${ }^{12}$ Moreover, according to Mendelsohn that "second category" is the "victim with minor guilt". This victimization is perpetrated in some part due to ignorance. Simply, the victim inadvertently placed himself in harms' way". ${ }^{13}$ Compare with Stephen Schafer's typology, when there is guilt in victim's behavior, this type included as "precipitative victims". In his opinion these victims did something inappropriate because of where they were, how they were dressed, the way they acted, or what they

9 Tammy Garland, 2009, Mendelsohn's Typologies, in Janet K Wilson, "The Praeger Handbook of Victimology", Santa Barbara California: ABC-CLIO, LLC, p. 167.

10 Iswanto and Angkasa, op.cit., p. 28.

11 See also Yohanes Suhardin, "Tinjauan Yuridis Mengenai Perdagangan Orang Dari Perspektif Hak Asasi Manusia", Jurnal Mimbar Hukum, Vol. 20 No. 3, October 2008, p. 477.

12 Iswanto and Angkasa, loc.cit.

13 Tammy Garland, loc.cit. 
said; thus, their responsibility was only negligible". ${ }^{14}$

Based on types of the first and second victim, there is a correlation between victim's guilt and the application of law security toward them. By looking at the information from research informant of Banyumas Police Resort that stated the victim does not want to be a victim, so there is tendencies in wanting law security. The victim here could cooperate in investigating human trafficking issue and the application of law security for them.

Thirdly, it is "voluntary victim". According to the interview with research informant from Banyumas Police Resort, there are mistake from this type of victim where they are agree to be in human trafficking cycle consciously. Refer to victim typology by Mendelsohn, the third type in his typology called as

"The victim as guilty as the offender and voluntary victim". ${ }^{15}$ In his opinion "The third category holds that victimization is "voluntary", these victims are as guilty as the offender. They, in essence, assisted in the creation of their own victimization (i.e., a suicide pact)". ${ }^{16}$

Furthermore refer to Stephen Schafer's typology which is "self-victimizing victims". In his opinion these victims engaged in deviant and criminal behaviors in which they were partners with the offenders; thus, these victims were totally responsible. Examples are prostitutes, drug users, drunks, and gamblers. ${ }^{17}$ Fourth, "victim who completely innocent and because of victim's ignorance they become voluntary victim". This is often happen in human trafficking in form of sexual exploitation cases. From the interview with research informant from $\mathrm{Ba}$ nyumas Police Resort that at first the victim is classified as first and second type but as time goes by the victim accept the reality and they start to take the benefit; thus, they don't feel suffer or harm.

14 John Dussich, 2009, Schafer's Typologies, in Janet K Wilson, Op.Cit, p. 238.

15 Iswanto and Angkasa, Loc.Cit.

16 Tammy Garland, 2009, Mendelsohn's Typologies, in Janet $\mathrm{K}$ Wilson, loc.cit.

17 John Dussich, 2009, Schafer's Typologies, in Janet K Wilson, loc.cit.
Referring to type 3 and type 4 of the victim, there is a correlation of the victim's mistake and the enforcement of legal protection for himself. According to a research informant from the element of Banyumas Resort Police, the victim does not feel harmed so it is hardly possible if the victim would reveal the case or fight for the right to get the legal pretection. The mentality of the victim is hard to be developed, uncooperative, and potential to be permanent victim which means that he/she will be the victim of human trafficking. This is more obvious as it is cleared in the interview of the research informant from PPT-PKBGA. According to the interview, in certain cases, the victim makes peace with the offender without his guidance parties accompanying. Thus, it makes the process is inhibited.

There is another factor influencing the enforcement of legal protection. According to Lawrence Mayr Friedman, ${ }^{18}$ there are three components required in legal system. They are structural, substantive, and cultural components. Related to them, there is still the weakness within it. First, based on the result of the interview with the PPT-PKBGA element, there is a limitation number of the PPT-PKBGA personnel; the limitation of budget, facilities and infrastructure in PPT-PKBGA; there is no cooperation between PPT-PKBGA and The Indonesian Witness and Victim Protection Agency (LPSK) in Faculty of Law Universitas Jenderal Soedirman. It is in line with the statement of the informant from Banyumas Resort Police which informs that the police do not have the Information Technology Facility (ITF) to do the tracking of human trafficking offender. It will result in the reveal of human trafficking case in which the role of The Regional Police is needed.

Second, the PPT-PKBGA, Banyumas Resort Police and Public Prosecutor do not attempt to give the concrete guidance in submitting the restitution. Third, referring to the data collected, there is differentiation between the data recapitulation of human trafficking case hand-

18 Rani Hendriana, "Perlindungan Hukum Tindak Pidana Terorisme: Antara Desiderata dan Realita", Jurnal Kosmik Hukum, Vol. 16 No. 1, January 2016, p. 34. 
led by the Banyumas Resort Police and the data recapitulation handled by the PPT-PKBG particularly about the number of cases and victims. It indicates that the recapitulations have not been conducted comprehensively among those institutions.

Fourth, the weakness of the law enforcement, which does not stand with the justice for the victim, can be seen in the public prosecutor's charge and the judge's verdict. According to Table 1 , on the case in 2005, the judge's verdict is lower than the public prosecutor's charge. It shows the lack of judge commitment to wipe out the human trafficking. It also happened in case occurred in 2006. The public prosecutor's charge is lower than the judge's verdict. The matter in which the public prosecutor and the judge do not employ the maximum criminal punishment, as what it should be according to Law Number 21 Year 2007 and Law Number 35 year $2014,{ }^{19}$ is also necessary to be criticized. It absolutely contrasts to the torture suffered by the victims who are women and children.

Related to the substantive component, the researchers find the substantive weakness. First, Government Regulation Number 44 Year 2008 on Giving Compensation, Restitution and Aids still has not been updated yet. This matter needs to be criticized since the regulation on medical and psycho-social aids is limited for the victims of severe violation of Human Rights so that it does not cover the victims of human trafficking. Second, Law Number 35 Year 2014 does not mention specifically how the detailed explanation regarding the protection of children who become the victims of kidnapping or human trafficking. ${ }^{20}$ Third, Banyumas Regency has not had Regional Regulation which specifically regu-

19 Compare with Yohanes Suhardin, Op.Cit, p. 477-479; see also Ahmad Syaufi, "Perlindungan Hukum terhadap Perempuan dan Anak Korban Tindak Pidana Perdagangan Orang", Muwazah, Jurnal Kajian Gender, Vol. 3 No. 2 December 2011, pp. 458-459.

20 I Nelsa Fadila, "Upaya Perlindungan Hukum Terhadap Anak Sebagai Korban Tindak Pidana Perdagangan Orang", Jurnal Hukum dan Peradilan, Vol. 5 No. 2, July 2015, p. 192 lates about the victims of human trafficking. ${ }^{21}$ Legal culture of society surrounding the victims also becomes the obstacle. Based on interview with the informant from Banyumas Regional Police, there is still tendency of society to give negative labelling to women and children who become the victims of human trafficking rather than participate in reintegrating and rehabilitating them socially.

\section{Conclusions}

There are several conclusions based on the discussion above. First, legal protection for women and children as the victims of human trafficking in Banyumas Regency has not been stood on Victimology perspective that is oriented to the victims' needs. It can be seen that there is still lack of preventive legal protection. The aid of social or psycho-social rehabilitation has not been optimal yet and there has not been accompaniment of restitution submission. Second, the behavior of victims in responding to legal protection toward them becomes the main factor that obstructs the success of legal protection implementation. Another obstructing factor is that there is still weakness either in legal structure, legal substance, or legal culture of society.

\section{Suggestions}

First, legal protection which is preventive needs to be conducted comprehensively and continuously toward women and children that are possible to be the victims. Second, the commitment of related institution which relies on the victims' needs must be increased such as accompaniment of restitution submission, social/psycho-social rehabilitation (formal and non-formal education), continuous internal founding of the victims, law enforcement that is oriented to victims' justice and socialization to

21 Compare with M. Ulil. Absor, “Advokasi Penanganan Korban Tracfficking Perempuan dan Anak Lesson Learnt dalam Advokasi Kebijakan di Kabupaten Banyuwangi Jawa Timur", Welfare, Jurnal Kesejahteraan Sosial, Vol. 1, No. 2 December 2012, pp. 256-257; See also Noer Indriati, "Pengembangan Model Perlindungan Hukum Terhadap Anak Sebagai Korban Pedagangan di Indonesia", Jurnal Dinamika Hukum, Vol. 14 No. 3, September 2014, p. 406. 
society not to give negative label-ling to the victims of human trafficking. Third, any resource in PPT-PKBGA and Banyumas Sub-regional Police must be maximized, building cooperation with LPSK Unsoed. Fourth, there should be regulation which organizes legal protection toward children as the victim of human trafficking, implementer regulation as the substitution of Government Regulation Number 44 Year 2008 must be issued soon, and there should be Regional Regulation of Banyumas Regency that regulates legal protection of the victims of human trafficking.

\section{References}

Absor, M. Ulil. "Advokasi Penanganan Korban Tracfficking Perempuan dan Anak Lesson Learnt dalam Advokasi Kebijakan di Kabupaten Banyuwangi Jawa Timur". WelfareJurnal Kesejahteraan Sosial. Vol. 1. No. 2 December 2012. Pp: 255-276;

Barus, Zulfadli. "Analisis Filosofis Tentang Peta Konseptual Penelitian Hukum Normatif dan Penelitian Hukum Sosiologis". Jurnal Dinamika Hukum, Vol. 13 No. 2. May 2013. Pp. 307-317. DOI: $10.20884 / 1 . j d h$. 2013.13.2. 212;

Bintoro, Rahadi Wasi. "Implementasi Mediasi Litigasi Di Lingkungan Yurisdiksi Pengadilan Negeri Purwokerto". Jurnal Dinamika Hukum. Vol. 14 No. 1. January 2014. Pp. 1324. DOI: 10.20884/1.jdh.2014.14.1.273;

Dussich, John. 2009. Schafer's Typologies, in Janet K Wilson. "The Praeger Handbook of Victimology". Santa Barbara California: ABC-CLIO, LLC;

Fadila, I Nelsa. "Upaya Perlindungan Hukum Terhadap Anak Sebagai Korban Tindak Pidana Perdagangan Orang". Jurnal Hukum dan Peradilan. Vol. 5 No. 2. July 2015. Pp. 181-194. DOI: 10.25216/JHP.5.2. 2016.181-194;

Garland, Tammy. 2009. Mendelsohn's Typologies, in Janet $\mathrm{K}$ Wilson. "The Praeger Handbook of Victimology". Santa Barbara California: ABC-CLIO, LLC;

Hattu, J. "Perlindungan Hukum Terhadap Korban Kejahatan Ekonomi Di Bidang Perbankan”. Jurnal Sasi, Vol. 16 No. 4. October- December 2010. Pp. 36-42;
Hendriana, Rani. "Perlindungan Hukum Tindak Pidana Terorisme: Antara Desiderata dan Realita". Jurnal Kosmik Hukum. Vol. 16 No. 1 January 2016. Pp. 30-41;

Hidayat, Maslihati Nur. "Upaya Pemberantasan dan Pencegahan Perdagangan Orang Melalui Hukum Internasional dan Hukum Positif Indonesia". Jurnal Al-Azhar Indonesia Seri Pranata Sosial. Vol. 1 No. 3. March 2013. Pp. 163 - 175;

Indriati, Noer. "Pengembangan Model Perlindungan Hukum Terhadap Anak Sebagai Korban Pedagangan di Indonesia". Jurnal Dinamika Hukum. Vol. 14 No. 3 September 2014. Pp. 406-418. DOI: 10.20884/1. jdh.2014.14.3.307;

Iswanto and Angkasa. 2011. Viktimologi. Purwokerto: Faculty of Law Universitas Jenderal Soedirman.

Jamaa, La. "Perlindungan Korban Kekerasan Dalam Rumah Tangga Dalam Hukum Pidana Indonesia". Jurnal Cita Hukum, Vol. I No. 2 December 2014. Pp. 249-272. DOI: 10. 15408/jch.v1i2.1467;

Sudaryono. "Kekerasan Pada Anak: Bentuk, Penanggulangan, dan Perlindungan Pada Anak Korban Kekerasan”. Jurnal Ilmu Hukum. Vol. 10 No. 1. March 2007. Pp. 87102;

Suhardin, Yohanes. "Tinjauan Yuridis Mengenai Perdagangan Orang Dari Perspektif Hak Asasi Manusia. Jurnal Mimbar Hukum. Vol. 20 No. 3. October 2008. Pp. 473-486. DOI: 10.22146/jmh.16289;

Syaufi, Ahmad. "Perlindungan Hukum terhadap Perempuan dan Anak Korban Tindak Pidana Perdagangan Orang". Muwazah Jurnal Kajian Gender. Vol. 3 No. 2. December 2011. Pp. 456-465. 